\title{
Enzyme-Silicon Studies of Gibberellic Acid-Treated Sugarcane During the Post Growth-Stimulatory Phase
}

\author{
Alex G. Alexander, Rafael Montalvo-Zapata, and Ashok Kumar ${ }^{1}$
}

\section{INTRODUCTION}

Gibberellic acid (GA) is a promising chemical for the increase of sucrose yield by sugarcane $(9,10,11,12,16,18,21,24){ }^{2}$ However, an important problem is the short duration of its growth-stimulating activity. In the greenhouse $(9,10,11), 3$-months old plants sprayed with 0.01 percent GA have given significant internode elongation and increased sucrose content within about 2 weeks. Growth and sugar effects reach a peak at about 4 weeks. Internodes laid down at this time will often be 2 to 3 times longer than those formed prior to treatment. By 6 weeks GA activity is clearly waning. At about 8 weeks sucrose values will be near normal, and, quite curiously, emerging internodes are found in a shortened, almost stunted condition when compared with internodes of the pretreatment period. This suggests that the plants' growth potential does not return to pretreatment levels even though stimulation has ceased.

A somewhat similar growth pattern is observed in the field after GA application with various aerial or ground equipment. Effective means for prolonging GA activity include more efficient methods of application, higher GA concentrations, and split or multiple treatments designed to give a cumulative yield superior to that gained with a single application.

Unfortunately, very little is known about the biochemistry of oncestimulated cane. Some very difficult questions can be put forward in very simple terms: After 6, 8, or 10 weeks have passed, are we still dealing with the same kind of sugarcane plant? Biochemically speaking, will a given GA level cause an identical effect a second or a third time? Is the plant still "attuned" to GA so that less is needed, or so that equal amounts will give a predictable cumulative action? Conversely, is the biochemistry now "geared" to growth decline so that some GA is needed just to revive the pre-GA growth capability?

The present paper summarizes enzyme-sugar and enzyme-silicon relationships in sugarcane 9 weeks after treatment with GA. The plants were grown in the greenhouse under strict water and nutritional control. Theoret-

1 Plant Physiologist, Assistant Chemist, and Assistant Plant Physiologist, respectively, Agricultural Experiment Station, Mayagüez Campus, University of Puerto Rico, Rio Piedras, P.R.

2 Italic numbers in parentheses refer to Literature Cited, p. 94-5. 
ically they needed a new GA treatment if high growth activity were to be continued. Our immediate interest lay in determining whether several enzymes intimately related to sucrose were performing in a manner characteristic of non-GA treated plants. To accomplish this, three objectives were attempted: 1, To induce upward sucrose trends with silicon (Si) given daily as a nutrient-solution supplement; 2 , to establish definite enzyme-activity correlations with the newly-established sucrose levels; and 3, to demonstrate that enzyme behavior trends in GA-treated plants, but ones no longer stimulated, returned to patterns comparable with those of untreated plants.

\section{MATERIALS AND METHODS}

A high-tonnage variety, P.R. 980, was grown in the greenhouse in accordance with the sand-culture technique described previously (1). All seedlings received a balanced, Si-free nutrient solution once daily until treatments were begun at 12 weeks of age. ${ }^{3}$

Four Si and two GA treatments were given in $2 \times 4$ factorial combinations in a randomized block design. There were three replicates. $\mathrm{Si}\left(\mathrm{Na}_{2} \mathrm{SiO}_{3}\right.$. $9 \mathrm{H}_{2} \mathrm{O}$ ) was applied as a nutrient-solution supplement at rates of 0,100 , 250, and 500 p.p.m. of elemental Si. Nutrient solutions were provided at about 2:00 p.m. each day except Sunday. All containers were flushed once each day with tap water and twice on Sundays. GA levels were 0 and 0.01 percent of the pure acid. ${ }^{4}$ Tween 20 was used as a wetting agent at the rate of $1 \mathrm{ml} . / 1$. The zero-GA plants received Tween 20 in distilled water.

Plant samples were harvested at 9 weeks after GA spray for enzyme and sugar analyses. Leaf and immature storage tissues were quick-frozen, lyophilized, ground to pass a 60 -mesh screen, and stored at $-10^{\circ} \mathrm{C}$. Leaf sheaths were retained for percent-moisture determinations. Stalks were ground with a small laboratory mill for Brix and polarization analyses. Juice samples were frozen as soon as the stalks were milled. These later were thawed, clarified with the centrifuge, reclarified with $\mathrm{ZnSO}_{4}$ and $\mathrm{Ba}(\mathrm{OH})_{2}$ (20), and analyzed for sucrose by the resorcinol method (17).

Clarified water extracts of the tissue powder were assayed colorimetrically for total ketose by the resorcinol method of Roe (22) and for sucrose by the modification of Cardini et al. (17). Fructose was estimated by subtracting sucrose values from those of total ketose.

Protein was precipitated from water extracts with solid ammonium sulfate as described previously (1). The 0-80 percent fraction was used for enzyme

- Nutrient concentrations, expressed as milliequivalents per liter, were provided as follows: Nitrate, 10; phosphate, 6 ; potassium, 5 ; calcium, 3 ; magnesium, 2 ; and sulfate, 2. Micronutrients, expressed as parts per million, were given as follows: Boron, 0.05; copper, 0.02; manganese, 0.50 ; zinc, 0.05 ; molybdenum, 0.01 ; and iron, 1.0 .

4 Supplied by Chas. Pfizer \& Co., Inc., New York, New York. 
analyses following 2 hours dialysis against two changes of distilled water. Acid phosphatase and ATP-ase were assayed in accordance with methods described earlier (3), as was amylase (4), invertase (5), peroxidase (6), and polyphenol oxidase (7). The method of Sutherland et al. (23) was used to determine the protein content of enzyme preparations. Enzyme action was computed as specific activity (activity units per milligram of protein).

TABLe 1.-Growth values for sugarcane given variable Si as a daily nutrient-solution supplement, and treated once with foliar GA nine weeks prior to harvest ${ }^{1}$

\begin{tabular}{|c|c|c|c|c|c|c|c|c|c|c|}
\hline \multirow{4}{*}{$\begin{array}{c}\text { GA (percent } \\
\text { solution) }\end{array}$} & \multicolumn{10}{|c|}{ Mean values for- } \\
\hline & \multicolumn{5}{|c|}{ Total fresh weight (s./plant) } & \multicolumn{5}{|c|}{ Stalk weight (g./stalk) } \\
\hline & \multicolumn{4}{|c|}{ Si (p.p.m.)- } & \multirow{2}{*}{ Mean } & \multicolumn{4}{|c|}{ Si (p.p.m.)- } & \multirow{2}{*}{ Meno } \\
\hline & $\mathbf{0}$ & 100 & 250 & 500 & & $\mathbf{0}$ & 100 & 250 & 500 & \\
\hline 0 & 575 & 523 & 411 & 378 & 472 & 198 & 210 & 153 & 116 & 169 \\
\hline & & & & & & & & & & \\
\hline \multirow[t]{2}{*}{ Mean } & 552 & 532 & 464 & 363 & & 196 & 205 & 175 & 131 & \\
\hline & \multicolumn{4}{|c|}{ Internode length (inches) } & & \multicolumn{4}{|c|}{ Sheath moisture (percent) } & \\
\hline 0 & 4.3 & 4.6 & 3.9 & 3.7 & 4.1 & 80.4 & 80.0 & 77.2 & 79.2 & 79.2 \\
\hline 0.01 & 5.3 & 5.4 & 5.3 & 5.1 & 5.3 & 78.5 & 78.3 & 79.2 & 80.8 & 79.2 \\
\hline Mean & 4.8 & 5.0 & 4.6 & 4.4 & & 79.5 & 79.2 & 78.2 & 80.0 & \\
\hline
\end{tabular}

1 Each figure represents the mean of three replicates. Four uniform plants were harvested from each replicate.

\section{RESULTS AND DISCUSSION}

1. GROWTH RESPONSES TO GA AND SI

Although GA-treated plants produced several typically elongated internodes, successive internodes were progressively shortened. Growth stimulation was no longer evident at the time of harvest. The GA elongation of stalks as well as moderate fresh weight increases are recorded in table 1.

There were no visible growth symptoms for $\mathrm{Si}$ other than moderate stunting within the 500 p.p.m. treatment. Weight decline at the 250 and 500 p.p.m. Si levels are recorded in table 1. Plant tissues from the high $\mathrm{Si}$ treatment displayed a waxy, crisp, almost brittle texture, presumably caused by increased amounts of skeletal $\mathrm{Si}$. The $\mathrm{Si}$ growth suppression was not comparable to classical ripening as evidenced by generally high and constant sheath-moisture percentages (table 1). These plants had slowed their growth but remained green and succulent. 
Careful study of table 1 shows that GA growth "increases" were a result of GA countering the growth stress induced by $\mathrm{Si}$. This also was true for stalk weight (fig. 1, A) and to a lesser degree for internode length (fig. 1, B). Growth restrictions caused by 250 p.p.m. Si were completely eliminated by GA. This agrees with earlier findings showing more effective GA activity in cane restricted by temperature (16), water (11), nitrate (10), 6-azauracil (12), and foliar Si (9). The agronomic implication is that GA can give striking results, or none at all, depending on growth difficulties being experienced at the time of treatment.

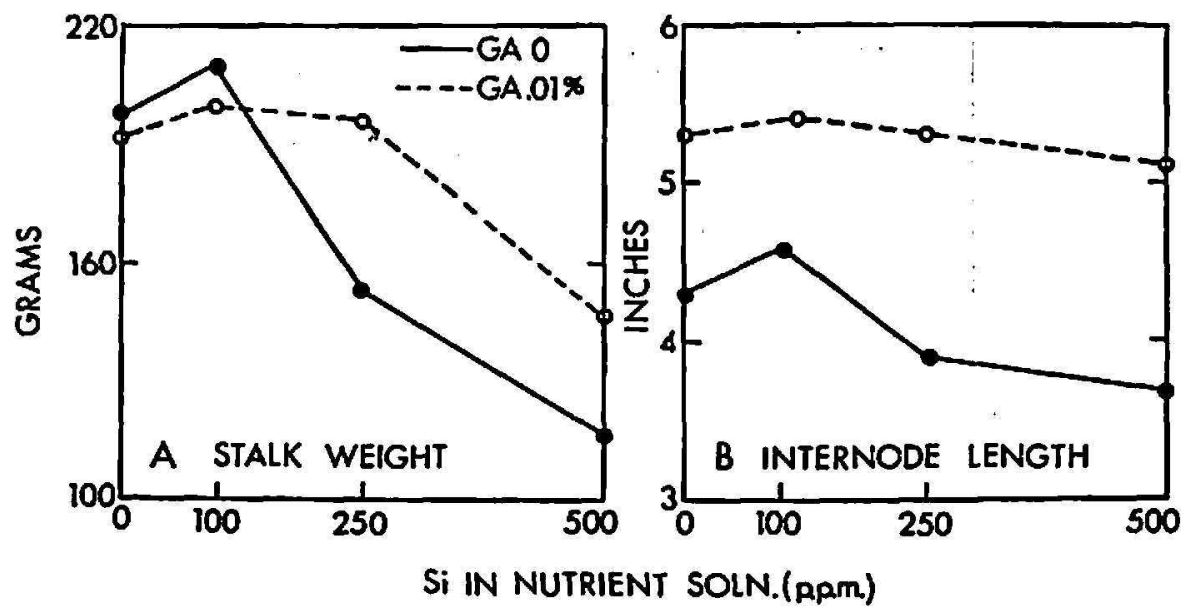

Fic. 1.-Growth decline in sugarcane supplied daily with increasing Si in sand culture, and treated with foliar GA 9 weeks before harvest.

\section{SUGAR RESPONSES to Ga AND SI}

Earlier work revealed that 500 p.p.m. Si caused significantly higher sucrose accumulations when supplied as a nutrient-solution supplement (9). This Si effect was currently verified and the range of effective Si concentration was defined more clearly (table 2 ). Figure 2 illustrates definite upward trends for sucrose in each of the three tissues analyzed. The effect was linear for immature storage tissue (fig. 2, A), while leaves revealed a slackened sucrose rise at the 500 p.p.m. level (fig. 2, B). Mature storage tissue did not accumulate additional sucrose when more than 250 p.p.m. $\mathrm{Si}$ was supplied (fig. $2, \mathrm{C}$ ). This may reflect a lag between the rate of sucrose synthesis and rate of final deposition in the stalk. Nonetheless, taking into account the growth suppression by 500 p.p.m. $\mathrm{Si}$, this amount was at least twice the level needed for optimum sucrose production.

The positive effect of $\mathrm{Si}$ on leaf sucrose implies some relationship between $\mathrm{Si}$ and photosynthesis. It has been shown recently that foliar Si can "protect" green-leaf tissues from the destructive action of Paraquat ${ }^{5}$ and

${ }^{5} 1,1^{\prime}$ dimethyl-4,4-bipyridinium-bis-dimethyl sulfate, commercially known as Gramoxone. 
TABLE 2.-Sucrose content of sugarcane given variable Si as a daily nutrient-solution supplement, and treated once with foliar GA nine weeks before harvest ${ }^{1}$

\begin{tabular}{|c|c|c|c|c|c|c|}
\hline \multirow{2}{*}{ Tissue } & \multirow{2}{*}{$\begin{array}{c}\text { GA } \\
\text { (percent solution) }\end{array}$} & \multicolumn{4}{|c|}{ Si (p.p.m.)- } & \multirow{2}{*}{ Mean } \\
\hline & & 0 & 100 & 250 & 500 & \\
\hline Leaf & $\begin{array}{c}0 \\
05 \\
\text { Mean }\end{array}$ & $\begin{array}{l}36.5 \\
38.7 \\
\\
37.6\end{array}$ & $\begin{array}{r}M \\
43.7 \\
45.1 \\
44.4\end{array}$ & $\begin{array}{l}- \\
53.5 \\
49.2 \\
51.3\end{array}$ & $\begin{array}{l}59.7 \\
55.9 \\
57.8\end{array}$ & $\begin{array}{l}48.4 \\
47.2\end{array}$ \\
\hline Immature storage & $\begin{array}{c}0 \\
05 \\
\text { Mean }\end{array}$ & $\begin{array}{l}56.4 \\
51.7 \\
\\
54.1\end{array}$ & $\begin{array}{r}M \\
64.5 \\
69.8 \\
67.2\end{array}$ & $\begin{array}{l}- \\
70.5 \\
62.6 \\
66.6\end{array}$ & $\begin{array}{l}83.5 \\
60.2 \\
71.9\end{array}$ & $\begin{array}{l}68.7 \\
61.1\end{array}$ \\
\hline Stalk & $\begin{array}{r}0 \\
05 \\
\text { Mean }\end{array}$ & $\begin{array}{r}88 \\
182 \\
\\
135\end{array}$ & $\begin{array}{c}147 . \text { of } \\
140 \\
159\end{array}$ & $\begin{array}{c}\text { Iled juic } \\
175 \\
170 \\
173\end{array}$ & $\begin{array}{l}170 \\
168 \\
\\
169\end{array}$ & $\begin{array}{l}145 \\
173\end{array}$ \\
\hline
\end{tabular}

2 Each figure represents the mean of three replicates.
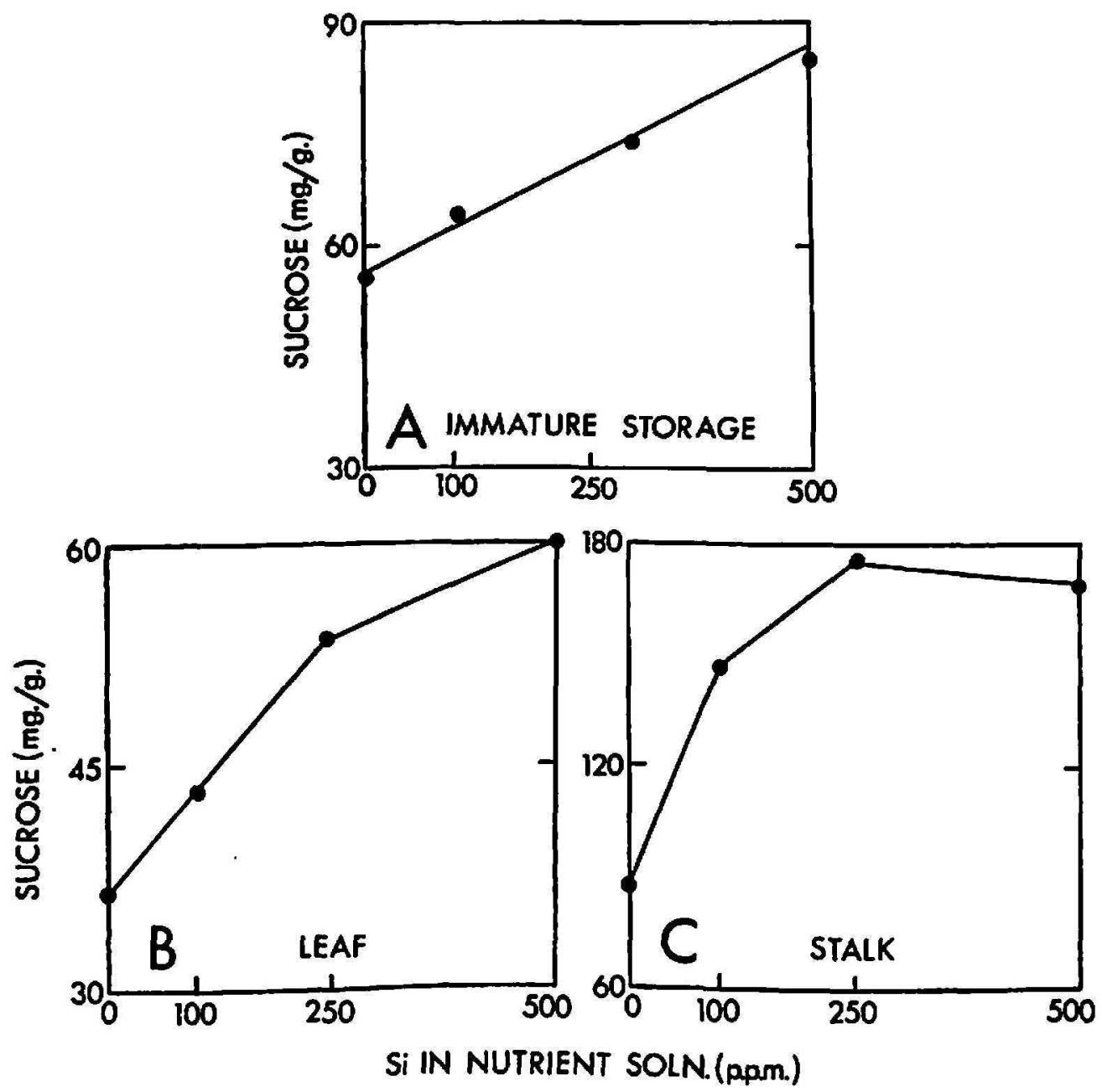

Fig. 2.-Increased sucrose content of different sugarcane tissues in response to increasing Si supply in sand culture. 
Diquat $^{6}(15)$. In accomplishing this, Si tended to moderate the chemicalinduced activity variances of several leaf enzymes. If a similar "protective" role is active against the lesser daily stresses of light, temperature, and water fluctuation, sucrose should gradually increase as a function of improved photosynthetic efficiency.
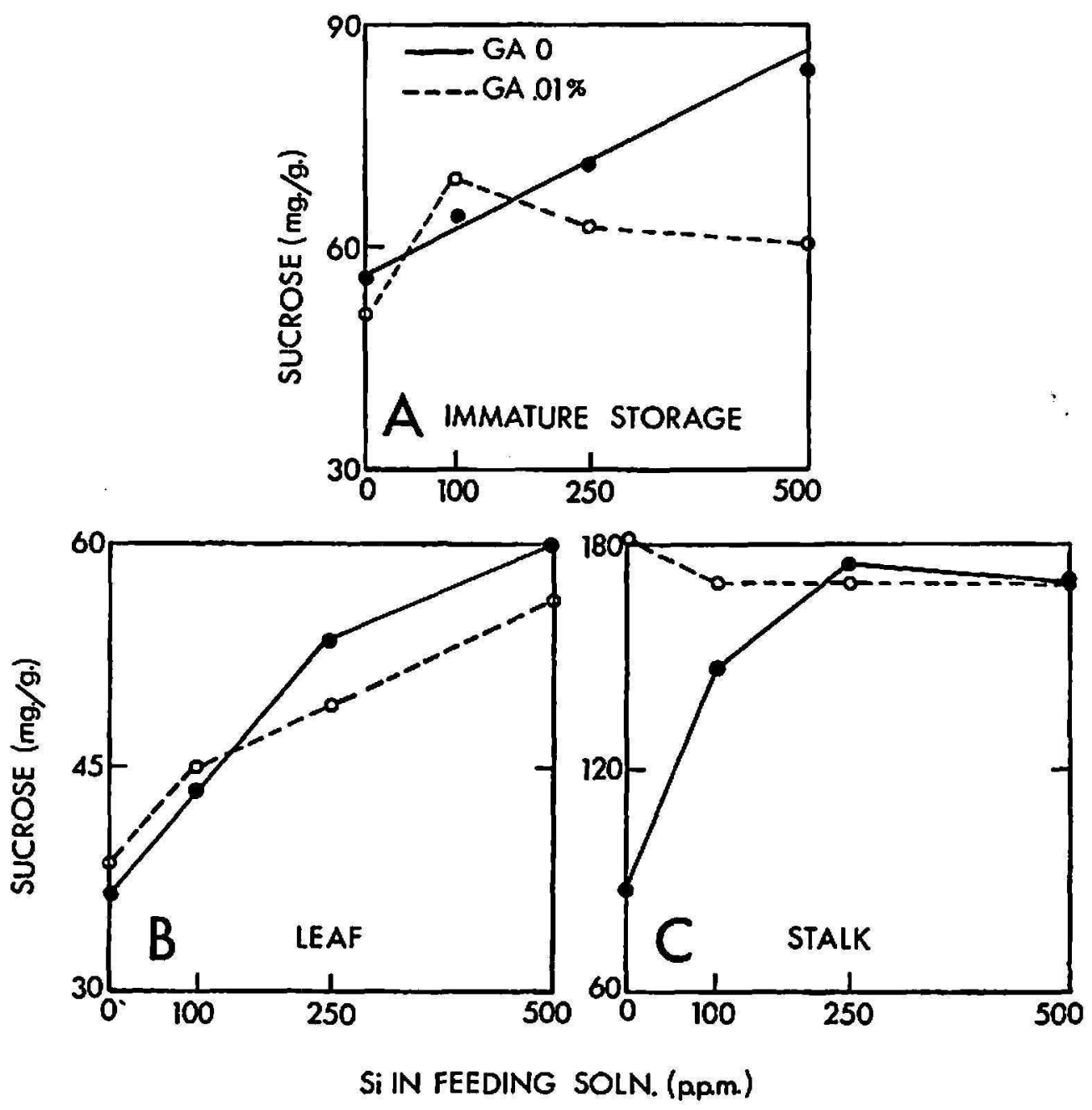

Fia. 3.-Changes in sucrose response to increasing $\mathrm{Si}$ as a result of foliar $\mathrm{GA}$ applied 9 weeks before harvest.

GA failed to increase the sucrose content of immature storage and leaf tissues at 9 weeks (fig. $3, A$ and B), although leaf sucrose was notably increased by daily Si treatment. That an earlier GA effect had occurred in leaves was indicated by the very high sugar level in stalks. Here sucrose content had been doubled by GA (fig. 2, C), a response which remained essentially constant regardless of Si. One would surmise that, as time passed, and as more internodes were laid down under a growth and sugar regime no

- 6,7-dihydrodipyrido $\left(1,2-a: 2^{\prime}, 1^{\prime}-c\right)$ pyrazidinium salt, commercially known as Reglone. 
TaBie 3.- Specific activity values for leaf enzymes of sugarcane given variable Si as a daily nutrient-solution supplement, and treated once with foliar GA nine weelss before harvest ${ }^{1}$

\begin{tabular}{|c|c|c|c|c|c|c|}
\hline \multirow{2}{*}{ Enzyme } & \multirow{2}{*}{$\underset{\substack{\text { (percent } \\
\text { solution) }}}{\mathbf{G A}}$} & \multicolumn{4}{|c|}{ Si (p.p.m.) - } & \multirow{2}{*}{ Mean } \\
\hline & & 0 & 100 & 250 & 500 & \\
\hline Phosphatase & $\begin{array}{l}0 \\
0.01 \\
\text { Mean }\end{array}$ & $\begin{array}{l}16.7 \\
15.8 \\
16.3\end{array}$ & $\begin{array}{l}14.8 \\
16.7 \\
15.8\end{array}$ & $\begin{array}{l}12.7 \\
14.8 \\
13.8\end{array}$ & $\begin{array}{r}8.8 \\
11.7 \\
10.3\end{array}$ & $\begin{array}{l}13.3 \\
14.2\end{array}$ \\
\hline ATP-ase & $\begin{array}{l}0 \\
0.01 \\
\text { Mean }\end{array}$ & $\begin{array}{l}27.6 \\
23.4 \\
25.5\end{array}$ & $\begin{array}{l}21.2 \\
25.2 \\
\\
23.2\end{array}$ & $\begin{array}{r}18.4 \\
20.4 \\
19.4\end{array}$ & $\begin{array}{l}15.0 \\
16.2 \\
15.6\end{array}$ & $\begin{array}{l}20.5 \\
21.3\end{array}$ \\
\hline Amylase & $\begin{array}{l}0 \\
0.01 \\
\text { Mean }\end{array}$ & $\begin{array}{r}41.6 \\
39.2 \\
40.4\end{array}$ & $\begin{array}{r}39.9 \\
62.5 \\
\\
51.2\end{array}$ & $\begin{array}{l}49.7 \\
55.5 \\
52.6\end{array}$ & $\begin{array}{l}36.3 \\
36.3 \\
\\
36.3\end{array}$ & $\begin{array}{l}41.9 \\
48.4\end{array}$ \\
\hline Peroxidase & $\begin{array}{l}0 \\
0.01 \\
\text { Mean }\end{array}$ & $\begin{array}{r}120 \\
74 \\
87\end{array}$ & $\begin{array}{l}104 \\
111 \\
\\
108\end{array}$ & $\begin{array}{r}71 \\
105 \\
88\end{array}$ & $\begin{array}{l}56 \\
83 \\
\\
70\end{array}$ & $\begin{array}{l}88 \\
93\end{array}$ \\
\hline Tyrosinase & $\begin{array}{l}0 \\
0.01 \\
\text { Mean }\end{array}$ & $\begin{array}{l}29.4 \\
22.7 \\
\\
26.1\end{array}$ & $\begin{array}{l}28.5 \\
31.7 \\
30.1\end{array}$ & $\begin{array}{l}23.9 \\
28.2 \\
\\
26.0\end{array}$ & $\begin{array}{l}21.7 \\
28.2 \\
\\
25.0\end{array}$ & $\begin{array}{l}25.9 \\
27.7\end{array}$ \\
\hline
\end{tabular}

1 Each figure represents the mean of three replicates.

longer stimulated by GA, the impact of high sucrose in early internodes would become progressively less distinct.

\section{FNZYME RESPONSES TO GA AND SI}

The clear sucrose trends established by $\mathrm{Si}$ were essential for success of this study. A second prerequisite was equally-clear enzyme responses, which could be correlated with changing sucrose level. This also was achieved with respect to several leaf enzymes known to be limiting factors in cane sucrose potential (table 3 ). These include: 1 , peroxidase; 2 , phosphatase; 3, ATP-ase; 4, tyrosinase; and 5, amylase.

Leaf peroxidase was strongly suppressed by increasing $\mathrm{Si}$ (fig. $4, \mathrm{~A}$ ). Its action curve is nearly a mirror image of leaf sucrose level. Si has recently been shown to inhibit peroxidase in vitro ( 8 ), as well as other oxidative and 
hydrolytic enzymes. Since the earliest of our sugarcane enzyme studies, peroxidase has shown an inverse activity relationship with sucrose content (1). The relationship has been noted periodically during the past 5 years $(2,13,14)$. Although the essential function of this enzyme has never been established (6), its effect upon sucrose appears to be one of several indirect and independent activities which are of little apparent concern to the plant $(19$, p. 364). It may at times serve as a "substitute" terminal oxidase, or it may be employed in oxidation of metabolites which might otherwise accumulate to toxic levels.

Quite significantly the prior GA treatment greatly altered peroxidase sensitivity to $\mathrm{Si}$ (fig. 4, A). The 100 p.p.m. Si treatment, which had in-
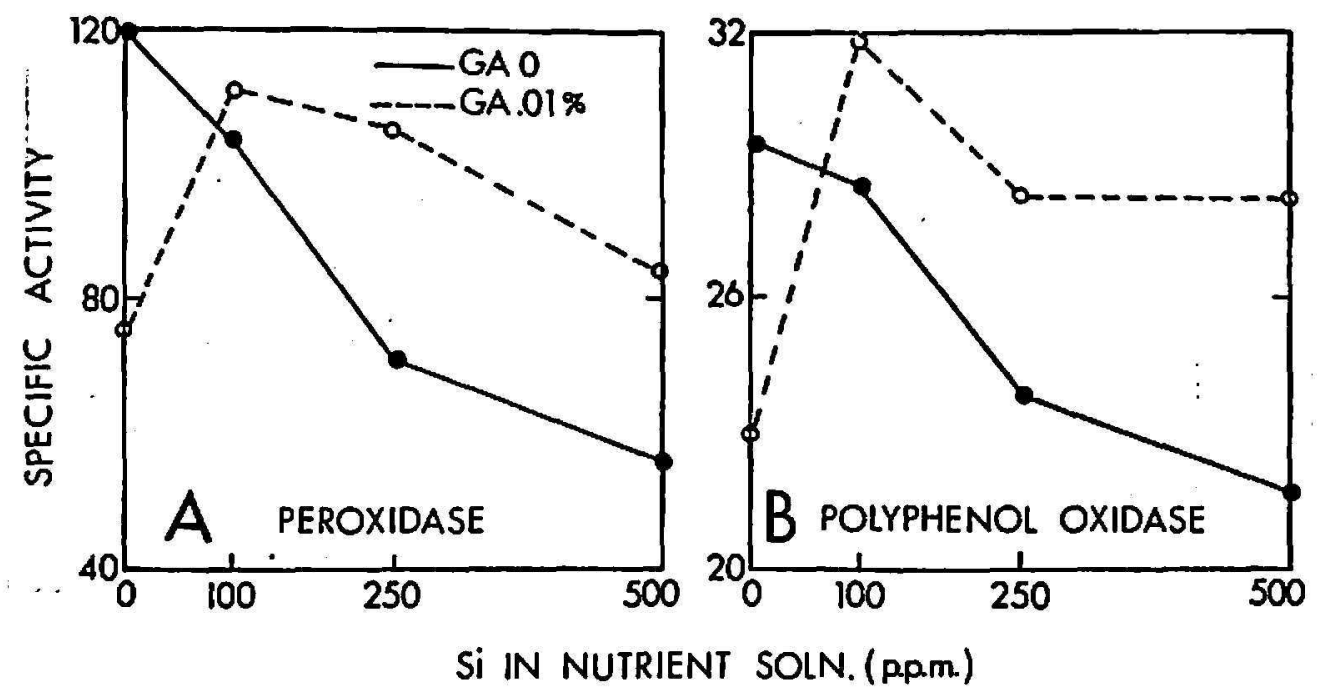

FIG. 4.-Leaf peroxidase and polyphenol oxidase decline in response to Si supplied in sand culture, and changes in enzyme sensitivity to $\mathrm{Si}$ as a result of foliar GA applied 9 weeks before harvest.

hibited peroxidase, served instead to increase the enzyme in GA-treated plants. Thereafter the higher Si concentrations did suppress peroxidase but not greatly; the enzyme scarcely descending back to the zero Si activity level. Thus, an investigator setting out to increase sucrose with 100 or 250 p.p.m. of Si, would likely trigger two distinct enzyme responses; one, a suppression in plants never given GA, and the other a stimulation in plants once treated but no longer responding to GA. From the standpoint of peroxidase, the scientist is confronted with two very distinct groups of plants.

The behavior patterns for polyphenol oxidase were almost identical to those described for peroxidase (fig. 4, B). This is a copper-requiring enzyme considered to be the principal terminal oxidase in aerial sugarcane tissues (7). All Si treatments suppressed the oxidase in plants not given GA. In GA-treated plants the 100 p.p.m. Si level caused increased-activity rather 
than suppression. The two higher Si treatments failed to bring the enzyme down to its activity level in zero Si plants. Again, an important enzyme responded in a vastly-altered manner to a sucrose-regulating treatment.

Acid phosphatase (fig. 5, A) and ATP-ase (fig. 5, B) responded to treatments very much like the oxidases. Definite susceptibility to Si inhibition is displayed by both enzymes. Much of this sensitivity is lost as a consequence of GA. The very great importance of ATP-ase and the acid phosphatase group ${ }^{7}$ has been discussed at length $(1,8)$. In essence, phosphatase activity must be kept low to insure sufficient pools of phosphorylated sucrose precursors for maximum sugar synthesis. An excessively active ATP-ase will destroy the essential high-energy source needed for optimum cane growth
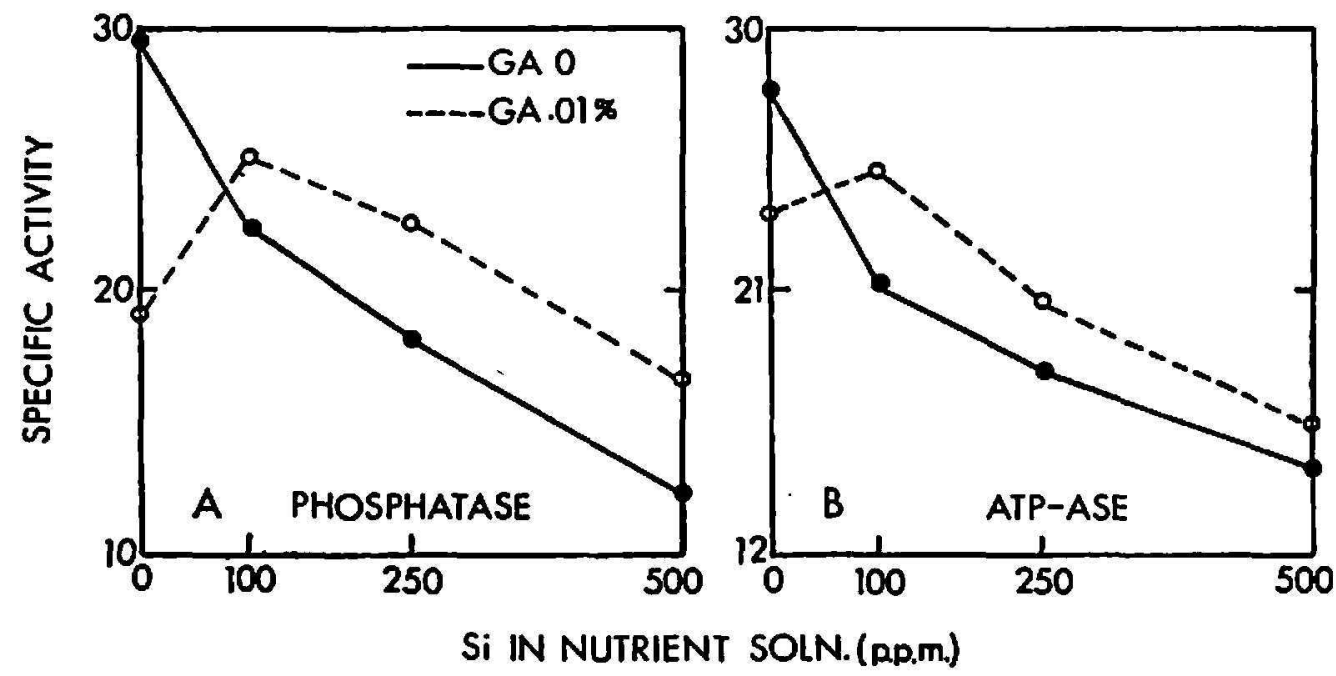

Fic. 5. - Leaf phosphatase and ATP-ase decline in response to $\mathrm{Si}$ supplied in sand culture, and changes in enzyme sensitivity to $\mathrm{Si}$ as a result of foliar GA applied 9 weeks before harvest.

and sugar production. Thus, the behavior of peroxidase, polyphenol oxidase, phosphatase and ATP-ase strongly suggests that very distinct biochemical regimes are operative well after the growth-stimulatory effects of GA have ceased. Consequently, GA treatments designed to improve the sugarproducing capacity of previously-treated plants might well yield distinctly different results than would plants never exposed to GA.

More than any other enzyme, amylase revealed a changed Si sensitivity as a consequence of earlier GA treatment (fig. 6). This enzyme is totally inhibited by $S i$ in the test tube (8), and the 250 to 500 p.p.m. Si treatments

$7 \beta$-glycerophosphate was employed here as a "catch-all" substrate. It is attacked by a series of phosphatases which hydrolyze such diverse organic phosphates as fructose-1-phosphate, fructose-6-phosphate, fructose-1,6-diphosphate, glucose-1phosphate, glucose-6-phosphate, uridine phosphates, phosphoglyceric acid, ribose phosphate, and others. 
did retard amylase in the plant. Nevertheless, the 100 p.p.m. Si level was strongly stimulatory, an effect made possible by the prior GA treatment.

\section{SIGNIFICANCE OF POST-GROWTH STMMULATORY GA-ENZYME RELATIONSHIPS}

Several lessons are underscored by the sucrose and enzyme data:

1. The dimension time emerges as a most dominant factor governing sucrose-enzyme relationships. Several years of experience with these enzymes tells us that the GA suppression of phosphatase, ATP-ase and the oxidases, at the zero Si level, should have led to striking sucrose increases in leaf and immature storage tissues. Such expectations are based on green-

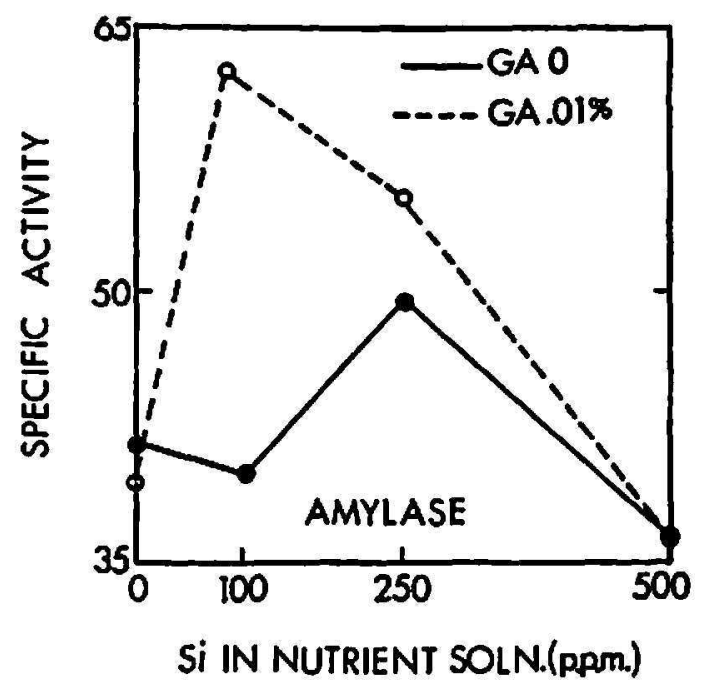

Fra. 6.-Changes in leaf amylase sensitivity to $\mathrm{Si}$ as a consequence of foliar GA applied 9 weeks before harvest.

house experiments of 3 to 5 weeks duration. This did not occur. Major sucrose increases were evident only in mature storage tissue. In simplest terms, the interpretation could be stated as follows: The desired enzyme suppression was achieved. Yet sucrose increases are detected only in stalk tissue. Higher leaf sucrose must therefore have occurred, but only temporarily. This might have been measured in the leaves or meristem at 3 or 4 weeks, but the sugar now has passed into permanent storage. The leaf effect will not reoccur by itself and evidence of its having happened will gradually disappear as newer internodes receive only average amounts of storage sucrose.

2. If once-treated cane does in fact become a biochemically distinct entity, then the practice of split or multiple applications might benefit from revaluation of increment concentration and timing. One approach currently being tested in Puerto Rico is the use of several increments applied within a few days of one another some 5 or 6 months before harvest. The 
underlying idea is to allow sufficient time for GA to be cleared from the receptor tissues (leaves), and for biochemical stimuli to begin, but not enough time for biochemical decline to set in. In effect, we hope to build up to a single, very powerful growth and sugar stimulus in young, erect cane, which will persevere throughout the preripening period.

3. The theory of Si "protective" roles for biochemical systems is strengthened by the enzyme data. These results, plus those of earlier studies (15), imply that enzyme-Si complexes form in the plant which are not strictly inhibitive, as would be the case in the test tube (8). Instead, there is a tendency to resist excessively high or low activity extremes. During the present studies, 100 p.p.m. Si appeared to stimulate phosphatase, peroxidase and tyrosinase by GA-treated plants (figs. 4 and 5). What actually happened is that GA had caused major enzyme suppression within the zero Si treatment, and 100 p.p.m. Si tended to shift these values back toward normal levels. Conversely, as the higher $\mathrm{Si}$ treatments approached growth-toxic levels, it was GA that helped to resist enzyme suppression.

\section{SUMMARY}

Enzyme-sucrose relationships were studied in immature sugarcane 9 weeks after foliar treatment with gibberellic acid (GA). Silicon (Si) was used to induce sucrose and enzyme behavior patterns which then were compared between GA-treated and non-GA treated plants. The ultimate purpose is exploration of the enzyme basis for the growth and sugar decline which supersedes GA growth stimulation. During the present study three objectives were attempted: 1 , To induce definite sucrose accumulations by daily use of $\mathrm{Si} ; 2$, to induce enzyme trends which could be correlated with changing sucrose level; and 3, to demonstrate that enzymes of cane no longer experiencing growth stimulation behave essentially the same as their counterparts in non-GA treated plants.

The following results were obtained:

1. Plants given foliar GA (0.01 percent) experienced initial internode elongation and increased fresh weight. The growth effects outwardly ceased by 9 weeks. Si at the 250 and 500 p.p.m. levels caused moderate growth stunting. This effect was markedly less severe in GA-treated plants.

2. Sucrose levels increased in leaf, immature storage, and stalk tissues in response to progressively higher $\mathrm{Si}$ supply. Optimum $\mathrm{Si}$ for growth and sucrose production lay between 100 and 250 p.p.m.

3. Evidence was found of a Si-moderating mechanism against relatively extreme shifts in leaf enzyme behavior.

4. Peroxidase, polyphenol oxidase, phosphatase, and ATP-ase were strongly suppressed in leaves as Si supply was raised. In each instance the enzyme sensitivity to $\mathrm{Si}$ was vastly altered in plants treated with foliar 
GA. Amylase sensitivity to Si was similarly changed by GA. 100 p.p.m. $\mathrm{Si}$ now caused amylase stimulation rather than retardation, and higher $\mathrm{Si}$ concentrations generally failed to cause major enzyme suppression.

5. Enzyme and sugar data were interpreted as follows: GA-induced growth and sucrose increases, while still easily detectable, were no longer in progress at 9 weeks. The necessary enzymatic basis for the growth and sucrose increases was no longer present. An enzyme status different both from non-treated and actively-stimulated plants was now operative.

6. It was concluded that additional GA treatments aimed at furthering growth and sugar production would be received by plants biochemically distinct from those given the initial treatment. Practical implications of the growth, sugar and enzyme data are discussed.

\section{RESUMEN}

Se estudió la interrelación entre las enzimas y la sacarosa en caña de azúcar inmadura a las 9 semanas después de recibir un tratamiento foliar con ácido giberélico (AG). Se usó silicio (Si) para inducir patrones de comportamiento de la sacarosa y las enzimas, que luego se compararon con los de plantas tratadas y no tratadas con AG. El objetivo final es explorar la base enzimática del crecimiento y la degradación del azúcar que sigue al crecimiento inicial estimulado por el AG. Para este estudio se fijaron tres objetivos: 1, Provocar acumulaciones definitivas de sacarosa mediante el uso diario de $\mathrm{Si}$; 2 , inducir tendencias enzimáticas que pudieran correlacionarse con niveles cambiantes de sacarosa; 3 , demostrar que cuando las enzimas de la caña de azúcar dejan de recibir un estímulo para el crecimiento, se comportan igual que las de aquellas plantas que no han sido tratadas con AG.

Se obtuvieron los siguientes resultados:

1. En las plantas tratadas con AG foliar (0.01 por ciento) ocurrió un alargamiento inicial de los entrenudos y un aumento en el peso verde. Los efectos visibles de crecimiento cesaron a las 9 semanas. El Si aplicado a concentraciones de 250 y 500 p.p.m. impidió moderadamente el crecimiento. Este efecto fue menos severo en las plantas tratadas con AG.

2. Los niveles de sacarosa aumentaron en los tejidos de las hojas, en el tejido reservante tierno y en los tallos como resultado de un aumento progresivo en las aplicaciones de Si. La concentración de Si más favorable para el crecimiento y la producción de sacarosa se mantuvo entre 100 y 250 p.p.m.

3. Se encontraron indicaciones de la presencia de un mecanismo moderador del Si que evita los cambios relativamente extremos en el comportamiento de las enzimas foliares.

4. La peroxidasa, oxidasa de polifenol, fosfatasa y ATP-asa fueron 
vigorosamente inhibidas en las hojas a medida que el suministro de Si se aumentaba. En todos los casos la sensitividad de la enzima al Si se alteró grandemente en las plantas tratadas foliarmente con AG. Igualmente se alteró la sensitividad de la amilasa al Si por la acción del AG. Concentraciones de 100 p.p.m. de Si estimularon la enzima en vez de retardarla, y generalmente concentraciones más elevadas apenas la inhibieron.

5. Los datos obtenidos sobre las enzimas y el azúcar se interpretaron como sigue: $\mathrm{El}$ crecimiento y los aumentos en la sacarosa ocasionados por el AG, aunque fácilmente determinables, cesaron a las 9 semanas. La base enzimática necesaria para el crecimiento y los aumentos en la sacarosa había desaparecido. Una composición enzimática distinta tanto en las plantas sin tratar como en las que fueron estimuladas la había sustituído.

6. Se concluyó que las plantas a las cuales se les suministraron tratamientos adicionales de $\mathrm{AG}$ con el fin de prolongar su crecimiento y aumentar la producción de azúcar, serían bioquímicamente distintas a las que se les suministró el tratamiento inicial. Se discuten las implicaciones prácticas que se derivan de los datos relativos al crecimiento, al azúcar y a las enzimas.

\section{LITERATURE CITED}

1. Alexander, A. G., Sucrose-enzyme relationships in immature sugarcane as affected by variable nitrate and potassium supplied in sand culture, J. Agr. Univ. P.R. 48 (3): 165-231, 1964.

2. Changes in leaf-sugar content and enzyme activity of immature sugarcane following foliar application of indole-3-acetic acid, 2,4-dichlorophenoxyacetic acid, and maleic hydrazide, J.Agr. Univ. P.R. 49 (1): 1-34, 1965.

3. - Hydrolytic proteins of sugarcane: The acid phosphatases, J. Agr. Univ. P.R. 49 (2): 204-28, 1965.

4. - Hydrolytic proteins of sugarcane: Amylase, J. Agr. Univ. P.R. 49 (3): 308$24,1965$.

5. - Hydrolytic proteins of sugarcane: The acid invertases, J. Agr. Univ. P.R. 40 (3): 287-307, 1965.

6. - Oxidizing enzymes of sugarcane: Peroxidase, J. Agr. Univ. P.R. 50 (1): 36$52,1966$.

7. — Oxidizing enzymes of sugarcane: Tyrosinase, J. Agr. Univ. P.R. 50 (2): 11330, 1966.

8. - In vitro effects of silicon on hydrolytic and oxidative enzymes of sugarcane, Proc. 1sth Congr. Int. Soc. Sugar Cane Technol., Taipei, Taiwan, 1968. Preprint no. A-03.

9. - Effects of foliar combinations of gibberellic acid and silicon on sucrose production by sugarcane, J. Agr. Univ. P.R. 52 (3): 218-26, 1968.

10. - Interrelationships of gibberellic acid and nitrate in sugar production and enzyme activity of sugarcane, J. Agr. Univ. P.R. 58 (1): 19-28, 1968.

11. - Relationships of gibberellic acid to water and phosphorus in the growth, sugar groduction, and enzyme behavior of sugarcane, J. Agr. Univ. P.R. 63 (3): 144-66, 1969.

12. - Growth, enzyme, and sugar responses of immature sugarcane to foliar treat- 
ment with 6-azauracil and gibberellic acid, J. Agr. Univ. P.R. 58 (4): 295-310, 1968.

13. Alexander, A. G., and Montalvo-Zapata, R., Enzyme studies of sucrose decline in sugarcane desiccated with Paraquat, J. Agr. Univ. P.R. 69 (4): 230-50, 1969.

14. - Enzymatic factors in the sucrose decline of sugarcane desiccated with Paraquat, Diquat, and Dinitrobutyl-phenol, J. Agr. Univ. P.R. 64(1): 28-49, 1970.

15. - The use of silicon to preserve sucrose in sugarcane desiccated with Paraquat and Diquat, J.Agr. Univ.P.R. (In press.)

16. Bull, T. A., The effects of temperature, variety, and age on the response of Saccharum spp. to applied gibberellic acid, Austral.J. Agr. Res. 16 (1): 77-84, 1964.

17. Cardini, C. E., Leloir, L. F., and Chiriboga, J., The biosynthesis of sucrose, $J$. Biol. Chem. 214: 149-55, 1955.

18. Coleman, R. E., Todd, E. H., and Coleman, O. H., The effects of gibberellic acid on sugarcane, Proc. Int. Soc. Sugar Cane Technol. 10: 588-603, 1959.

19. Fruton, J. S., and Simmonds, S., General Biochemistry, 2nd ed., John Wiley \& Sons, New York, N.Y., 1963.

20. Nelson, N. A., A photometric adaptation of the Somogyi method on the determination of glucose, $J$. Biol. Chem. 158: 375-80, 1944.

21. Nickell, L. G., and Tanimoto, T., Gibberellins ready for commercial evaluation, Ann. Rept. Exp. Sla. Haw. Sugar Planters' Assn., p. 12, 1965.

22. Roe, J. H., A colorimetric method for the determination of fructose in blood and urine, J. Biol. Chem. 107: 15-22, 1934.

23. Sutherland, E. W., Cori, C. F., Haynes, R., and Olsen, N. S., Purification of the hyperglycemic-glycogenolytic factor from insulin and from gastric mucosa, $J$. Biol. Chem. 180: 825-37, 1949.

24. Tanimoto, T., and Nickel, L. G., Re-evaluation of gibberellins for field use in Hawaii, Ann. Rept. Haw. Sugar Technol., 184-90, 1966. 